University of Nebraska - Lincoln

DigitalCommons@University of Nebraska - Lincoln

2016

\title{
Applying Ecological Systems Theory to Sexual Revictimization of Youth: A Review with Implications for Research and Practice
}

\author{
Samantha L. Pittenger \\ University of Nebraska-Lincoln \\ Terrence Z. Huit \\ University of Nebraska-Lincoln \\ David J. Hansen \\ University of Nebraska-Lincoln, dhansen1@unl.edu
}

Follow this and additional works at: https://digitalcommons.unl.edu/psychfacpub

Part of the Psychology Commons

Pittenger, Samantha L.; Huit, Terrence Z.; and Hansen, David J., "Applying Ecological Systems Theory to Sexual Revictimization of Youth: A Review with Implications for Research and Practice" (2016). Faculty Publications, Department of Psychology. 1032.

https://digitalcommons.unl.edu/psychfacpub/1032

This Article is brought to you for free and open access by the Psychology, Department of at DigitalCommons@University of Nebraska - Lincoln. It has been accepted for inclusion in Faculty Publications, Department of Psychology by an authorized administrator of DigitalCommons@University of Nebraska - Lincoln. 


\title{
Applying Ecological Systems Theory to Sexual Revictimization of Youth: A Review with Implications for Research and Practice
}

\author{
Samantha L. Pittenger, Terrence Z. Huit, and David J. Hansen \\ Department of Psychology, University of Nebraska-Lincoln, Lincoln, Nebraska, USA \\ Corresponding author - S. L. Pittenger, Department of Psychology, University of Nebraska-Lincoln, 238 Burnett \\ Hall, Lincoln, NE 68588, USA, telephone 402-472-3721, fax 402-472-6804, email frieden@huskers.unl.edu
}

\begin{abstract}
This article reviews the literature on sexual revictimization, integrating findings from studies with adult and youth samples and organizing research evidence within a social ecological framework. Multiple victimization experiences are common among children, adolescents, and adults with histories of child sexual abuse; they are associated with negative cumulative effects on the individual and, through these negative sequelae, perpetuate a cycle of victimization. While much of the research has focused on individual factors that promote revictimization, there is emerging evidence that external influences on the individual may influence risk for subsequent victimization. Specifically, family, perpetrators, and engagement with helping professionals may all mediate revictimization risk. Although limited evidence prevents conclusions regarding societal values, public policy, and law, these systems may also impact individual risk for experiencing multiple victimizations.
\end{abstract}

Keywords: revictimization, youth, child sexual abuse, social ecology

\section{Introduction}

Child sexual abuse (CSA) is a prevalent problem that disrupts developmental trajectories and has an impact on victims across their lifespan. While epidemiological data vary, an astonishing number of children experience sexual abuse each year (Friedenberg, Hansen, \& Flood, 2013) and consequently endure a number of negative outcomes in the form of 
psychological, behavioral, and neurobiological sequelae (De Bellis, Spratt, \& Hooper, 2011; Putnam, 2003). Rigorously designed studies have provided evidence for the pervasiveness of problems stemming from initial victimization experiences, shedding light on the longterm consequences that individuals experience (Polusny \& Follette, 1995), one of which is sexual revictimization. Over the past few decades, investigators have shown that experiences of sexual abuse heighten subsequent risk for victimization within childhood, adolescence, and adulthood (for reviews see Arata, 2002; Breitenbecher, 1999; Classen, Palesh, \& Aggarwal, 2005. The majority of research exploring factors that increase the risk of subsequent victimization has focused on symptomatology associated with initial abuse experiences (Grauerholz, 2000), which is often reported retrospectively by adult women; however, the issue may be best understood when viewed within a developmental model that accounts for individual, family, environment, and societal factors (Grauerholz, 2000; Matta Oshima, Jonson-Reid, \& Seay, 2014; Simmel, Postmus, \& Lee, 2012). The purpose of this paper is to review current research evidence regarding revictimization across the lifespan from a social-ecological developmental perspective, noting areas in need of further exploration and providing recommendations for future research and prevention efforts.

\section{Relationship between sexual abuse and revictimization}

CSA is associated with an increase in risk for subsequent sexual victimization (see Arata, 2002; Classen et al., 2005). This phenomenon has been termed "revictimization" and is here used to mean any victimization experience perpetrated by a different individual and occurring subsequently to an initial abuse occurrence (Barnes, Noll, Putnam, \& Trickett, 2009). Despite recent evidence that children and adolescents experience sexual revictimization, investigations have mostly focused on sexual assault in adulthood for individuals with CSA histories. These endeavors have greatly contributed to knowledge regarding the relationship between CSA and adult sexual revictimization, and there is promise that similar risk models may apply to youth.

In a meta-analysis of studies concerning revictimization, Roodman and Clum (2001) concluded that there was a definite relationship between CSA and adult sexual victimization. In fact, female victims of CSA experience rape or sexual assault in late adolescence or adulthood at a rate two to three times higher than nonabused women (Arata, 2002; Barnes et al., 2009; Coid et al., 2001; Desai, Arias, Thompson, \& Basile, 2002; Gidycz, Hanson, \& Layman, 1995). While 24-38\% of nonabused women report sexual victimization in adulthood (Banyard, Williams, \& Siegel, 2001; Barnes et al., 2009; Gidycz et al., 1995; Maker, Kemmelmeier, \& Peterson, 2001), as many as $72 \%$ of adult CSA victims report sexual revictimization (Messman \& Long, 1996); thus the relationship between CSA and adult victimization is not mere coincidence. Beyond contributing to the heightened likelihood of adult sexual victimization, CSA may actually predict its occurrence (Gidycz, Coble, Latham, \& Layman, 1993; Himelein, 1995; Roodman \& Clum, 2001). Classen et al. (2005) provided a thorough review of the adult revictimization literature to date, including crosssectional and longitudinal studies across clinical, community, and college samples from the United States and other countries. They concluded that two out of three women with a history of CSA are likely to endure subsequent sexual victimization (Classen et al., 2005). 
Given this evidence, it can confidently be asserted that CSA strongly impacts risk for sexual victimization in adulthood.

Sexual abuse in childhood has also been associated with revictimization prior to adulthood (Miron \& Orcutt, 2014). The few studies exploring revictimization as it occurs in childhood and adolescence suggest that it is a very real issue for individuals within these developmental periods, with reabuse rates between 20 and 39\% (Finkelhor, Ormrod, \& Turner, 2007; Swanston et al., 2002). Surveying 304 female teenagers, Krahe, ScheinbergerOlwig, Waizenhöfer, and Kolpin (1999) found that girls with a history of sexual abuse reported more unwanted sexual experiences in comparison to nonabused peers, coerced and/or forced intercourse in particular. In their survey of 2,000 children ages 10-16 years, Boney-McCoy and Finkelhor (1995) found that children with a prior report of CSA were 11.7 times more likely than those without a prior report to have experienced sexual abuse within the past year, an effect that persisted after taking into account repeat victimization by the same perpetrator. A large survey of adolescents also found CSA to be a predictor of sexual victimization within the past year (Smalls \& Kerns, 1993). Further, a retrospective survey of 520 women found that those who reported experiencing CSA were five times more likely to experience attempted or completed rape and three times more likely to experience sexual assault between the ages of 16 and 18 years (Fergusson, Horwood, \& Lynskey, 1997). Thus, sexual revictimization is commonly experienced by victims of CSA, occurs more frequently than can be considered chance, and has an impact on youth as well as adults.

\section{Effects associated with sexual revictimization}

Numerous studies provide evidence for the cumulative negative effects of multiple victimization experiences regarding individuals' psychological well-being. Green et al. (2000) conducted a large examination of the impact of multiple interpersonal traumatic events (e.g., sexual victimization) on psychological functioning. Reviewing questionnaire data from 2,507 female college students, the authors found that experiencing multiple interpersonal traumas was associated with significantly higher self-reported psychological distress compared to women reporting multiple noninterpersonal traumas and those experiencing single traumas (either interpersonal or noninterpersonal). In her review of the sexual revictimization literature, Arata (2002) concluded that revictimized women are likely to report more trauma, depression, and anxiety symptoms, more frequently develop dissociative disorders, and have lower self-esteem compared to nonvictimized women, those reporting child sexual assault only, and those reporting adult sexual assault only. A wide array of studies following suit has shown that victims of multiple instances of sexual violence tend to also report more psychological distress, suicidality and self-harm behaviors, poorer physical health, and more substance and alcohol use compared to those with single instances of victimization (Balsam, Lehavot, \& Beadnell, 2011; Casey \& Nurius, 2005; Fortier et al., 2009). Due to these cumulative effects, Barnes et al. (2009) identify continued victimization as having "far-reaching public health consequences" (p. 418).

Although there has been no formal investigation of the cumulative impact of revictimization on youth, it is clear that the psychosocial consequences of CSA are associated with 
risk for subsequent abusive episodes. For example, the emotional impact of CSA may place youth at higher risk for revictimization, which, in turn, increases risk for adult sexual assault. Utilizing data from the Developmental Victimization Survey, Cuevas, Finkelhor, Clifford, Ormrod, and Turner (2010) sought to explore predictors of revictimization for children and adolescents. Results indicated that reported psychological distress-calculated as an aggregate of depression, anxiety, and anger-predicted revictimization within one year of initial interview. Additionally, surveying 1,569 women, Humphrey and White (2000) found that those who have experienced victimization in both childhood and adolescence had the highest rates of sexual assault as young adults. Multiple victimizations appear to contribute to a feedback loop whereby the impacts of initial abuse increase vulnerability for subsequent victimization, potentially compounding negative psychological effects and further perpetuating abusive experiences.

Thus, sexual revictimization is a social concern not only because it exposes individuals to violence but also because it is associated with poorer psychosocial functioning and seems to perpetuate a cycle of victimization throughout the lifespan. Developing a better understanding of revictimization and striving earlier in individual development will help reduce the occurrence of sexual trauma and the associated behavioral and psychological sequelae. Therefore, it seems logical to view revictimization within a developmental framework that captures multiple important contexts of human development in order to achieve this heightened understanding.

\section{Bronfenbrenner's ecological systems theory}

CSA has very palpable and negative impacts on the developing individual, including insults to an integrated and healthy sense of self, impairments in social functioning, and influences to sexual development (Cicchetti \& Banny, 2014; Crowley, 2000; Noll, Trickett, \& Putnam, 2003). Thus CSA influences how the individual functions within society, and these developmental impacts in conjunction with the circumstances that led to initial abuse experiences may be the culprits to encouraging the cycle of victimization. To more fully explore this theory, abuse and revictimization should be considered from an ecological perspective, parsing out individual, familial, community, and societal influences on risk for harm and promotion of resilience.

The ecological approach to understanding human development was articulated by Urie Bronfenbrenner (1977) as a proposed solution to fully account for all influences on human development. Whereas prior theories of development examined the individual and family as the sole contexts for development, Bronfenbrenner recognized that external influences on the family, even those with which the individual may never directly interact, might have just as great an impact. Bronfenbrenner's model of development is continually evolving and is currently referred to as the bioecological model to account for an individual's genetic potential in addition to the environmental influence on development (Bronfenbrenner \& Ceci, 1994). For purposes of enhancing our understanding revictimization, however, the present paper focuses on the social ecology of maltreatment. Specifically, we will explore how the contexts of development may influence risk for repeat victimization. 
The propositions of Bronfenbrenner's bioecological model have particular value in attempting to understand revictimization from this perspective. Proposition 1 reiterates what others before Bronfenbrenner have argued, that development occurs through the proximal processes of interpersonal contexts as well as the interactions between an active being and their environment (Bronfenbrenner, 1994). Bronfenbrenner (1994) explains that abusive interactions "imply low levels of proximal processes because they reduce possibilities for progressively more complex reciprocal interaction" (p. 572) and that these types of interactions, as well as others that provide for low levels of proximal processes, promote the development of maladaptive interactions with others and the environment. Proposition 2 explains that the influence of proximal processes on the developing individual depends on a number of factors. Specifically, Bronfenbrenner (1994) refers to individual characteristics, the various environmental contexts of development, and the actual developmental outcome that is being examined.

The environment is an especially important component of these interdependent propositions. In Bronfenbrenner's model, there are five types of environmental contexts, or systems, within which development occurs: microsystems, mesosystems, exosystems, macrosystems, and chronosystems. Microsystems refer to those contexts in which the individual is immediately present and within which direct interactions between the developing individual and environment occur. Common microsystems include the family, school, peer groups, and the workplace. Mesosystems represent interactions between at least two of the aforementioned microsystems. For example, the relationship between family and school represents a widely studied microsystem, often examined in regard to impact on the individual's academic functioning and achievement (Bronfenbrenner, 1994). Expanding to more remote contexts of development, exosystems consist of relationships between at least two systems, one with which the individual is influenced directly, for example, the relationship between a child's parent and their parent's workplace. While a child may not interact with their caregiver's workplace, this system influences caregivers' moods, cognitions, and behaviors in ways that may carry over into the home environment and thus indirectly influence the individual. Bronfenbrenner also described macrosystems to capture cultural characteristics that permeate the other more proximal systems within which the individual develops. Finally, human development must be considered in light of the complexities of time, including age and era. Beyond mere age, chronosystems capture characteristics of the era in which one grows, incorporating both individual and environmental changes and consistencies across time. To draw from current social and political events, one might explore the influence of chronosystems by examining how opinions of marriage equality differ for those born in 1960 and 2000. In this example, it would be expected that a person's age when exposed to media coverage and legislative changes regarding marriage equality would influence their views of the matter.

Since its inception in the 1970s, the ecological framework has been used to account for the complexities of many conditions. For example, Bronfenbrenner's model was applied to the phenomenon of child maltreatment and widely disseminated by Jay Belsky (1989, 1993). Seeking to shed light on the etiology of child maltreatment, Belsky argued that it was the interplay of individual characteristics of children (also called ontogenic development), parent and family characteristics (microsystems), the community (exosystems), and 
broader cultural values (macrosystems) that influenced risk (Belsky, 1989). However, Belsky's developmental-ecological model of maltreatment appears to lack discussion of sexual abuse, and at some points even purposefully excludes it (e.g., Belsky, 1993). Despite this absence in the ecology literature, CSA and revictimization will be better understood when considered from this framework, as it enables researchers to examine the complex interactions within and between ecological levels that impact a child's risk (Sidebotham, 2001).

\section{Applying the bioecological model to revictimization}

Studies employing the ecological perspective regarding sexual revictimization have begun to emerge, although they continue to remain sparse. Extending the work of Heise (1998), who sought to integrate knowledge about violence against women into an ecological model, Grauerholz (2000) provided a review of the adult sexual revictimization literature urging future research endeavors to utilize this framework. Her review of evidence from research with adult samples thoroughly describes the interplay between individual characteristics, the contexts within which victimization occurs, and broader societal values that influence victims and perpetrators. At the individual, or ontogenic, level Grauerholz argued that factors such as the individual's historical experiences, including initial victimization occurrences, influence risk for revictimization. An especially important and widely examined factor at this level is psychopathology, although Grauerholz (2000) cautions that we are missing the big picture when such characteristics are the sole focus of investigations. Specifically, focusing on individual mental health functioning may encourage victim blaming. Thus, Grauerholz (2000) follows Belsky's model and describes factors at the micro-, exo-, and macrosystem levels that influence adult women's risk for revictimization. At the microsystem level, she states that female abuse victims may be at risk due to heightened likelihood of (a) exposure to potential perpetrators and (b) potential perpetrators being more likely to act aggressively. The most notable factor Grauerholz (2000) describes at the exosystem level is social disadvantage; however, only evidence relating to CSA and not revictimization was available at the time of her review (Fergusson et al., 1997; Mullen, Martin, Anderson, Romans, \& Herbison, 1994). At the macrosystem level, Grauerholz (2000) calls attention to the American public's penchant for blaming victims for their own misfortune, stating that this perpetuates victimization by labeling assaulted women as sexually promiscuous and damaged.

Fifteen years have passed since Grauerholz's review. Given the accumulation of new research evidence regarding risk for revictimization, it seems necessary to reevaluate the application of the theory. Additionally, with the emergence of research regarding revictimization prior to adulthood, we must examine this issue as it relates to children and adolescents. Figure 1 illustrates a systems approach to examining revictimization, using Belsky's (1989) conceptualization of maltreatment. Complex interactions across these levels are also examined within the confines of the person-process-context-time model described earlier. 


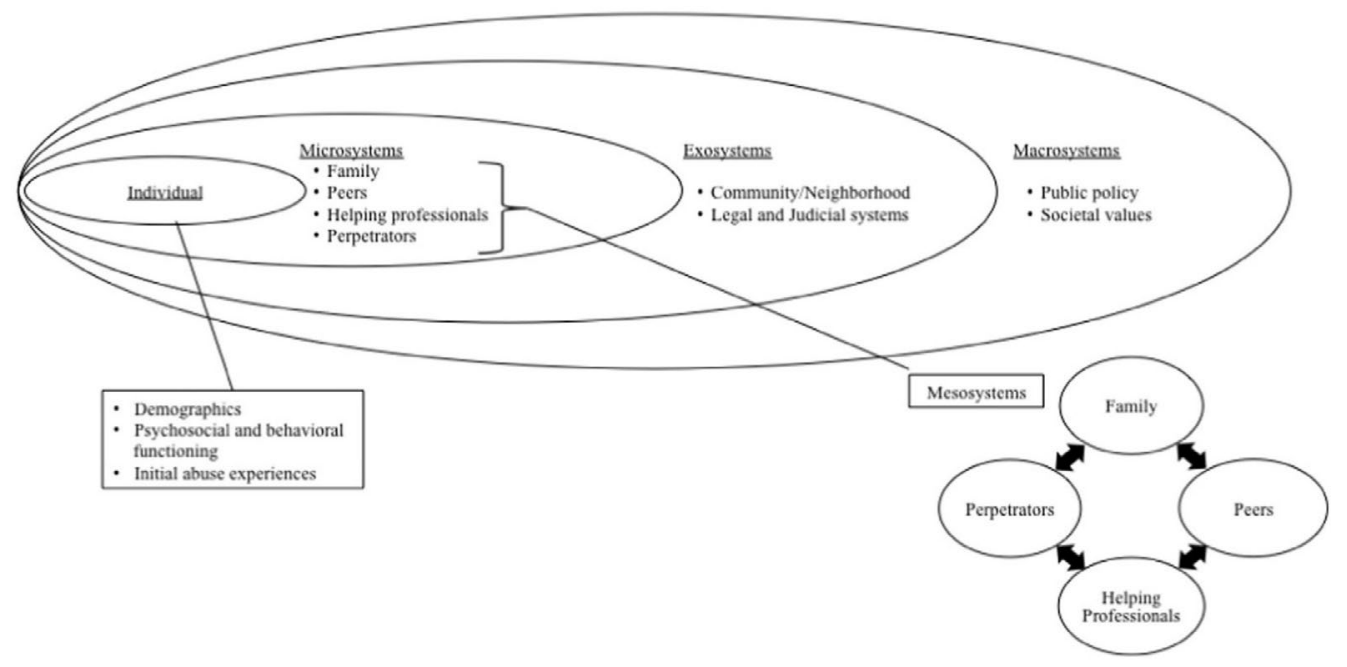

Figure 1. Ecological model of revictimization within childhood and adolescence. This figure illustrates the factors at each contextual level of development that may influence risk for revictimization of sexually abused youth.

\subsection{Ontogenic development}

Ontogenic development accounts for the individual's personal characteristics and how their experiential history influences interpersonal interactions (Grauerholz, 2000). Most of the revictimization literature has examined how factors at this level are associated with risk. Often, this includes the examination of psychological and behavioral functioning attributable to earlier life experiences such as sexual abuse (Arata, 2002). In addition to the effects of CSA, evidence implicates various demographic factors as well as characteristics of initial victimization experiences as influencing risk for subsequent victimization.

\subsubsection{Demographic variables}

There is some indication that and age and ethnicity may be associated with risk for sexual revictimization. Using data from a general population survey of women residing in Washington State, Casey and Nurius (2005) found that women reporting multiple victimizations with different perpetrators tended to be younger at the time of initial victimization. Simmel et al. (2012) interviewed 423 women to examine the influences of disclosing initial abuse experiences on risk for sexual revictimization in adulthood. Results suggested that initial abuse occurring within what the authors refer to as the "latency" period of childhood (ages 6-10 years) significantly contributed to an increased risk for subsequent victimization when compared to those experiencing CSA during the preschool years (Simmel et al., 2012). Another large-scale study surveying women enrolled in state universities found that victimization prior to the age of 14 nearly doubled the chances of revictimization in later adolescence (Humphrey \& White, 2000).

Race, ethnicity, and culture have not been thoroughly examined in regard to how they relate to sexual victimization, let alone revictimization. Furthermore, previously executed studies have provided inconsistent findings (Friedenberg et al., 2013). For example, while 
national data indicates that African American girls experience sexual abuse nearly twice as frequently as other ethnic groups, some studies have found that Hispanic women more frequently report history of CSA, and at least one study has found no differences in abuse prevalence based on ethnicity (Elliott \& Briere, 1992; Kalof, 2000; Sedlak et al., 2010). Shedding light on revictimization within childhood, Matta Oshima et al. (2014) followed a cohort of children from initial report of sexual abuse through age 18. Including all maltreatment types, they found that black children, particularly those from nonpoor families, had higher risk for a subsequent maltreatment report (Matta Oshima et al., 2014). Urquiza and Goodlin-Jones (1994) examined rates of adult sexual revictimization between White, African American, Latina, and Asian American women. They found that women with a history of CSA were more likely to experience rape in adulthood, regardless of ethnicity; however, $61.5 \%$ of African American women experienced revictimization, compared with $44.2 \%$ of White women, $40.0 \%$ Latinas, and $25.0 \%$ of Asian American women (Urquiza \& GoodlinJones, 1994). This evidence that revictimization may vary for different ethnic groups and may operate independently of poverty status suggests that this construct should be examined more closely in future research.

\subsubsection{Psychosocial and behavioral functioning}

A number of abuse sequelae have been implicated in increasing subsequent risk for victimization, namely psychological effects such as distress, posttraumatic stress disorder (PTSD), and maladaptive cognitions as well as difficulty with interpersonal relationships, increased substance and alcohol abuse, and increased sexual activity. This paper includes a limited discussion of the relevant literature, as multiple reviews exist on this topic (e.g., Arata, 2002; Classen et al., 2005; Messman-Moore \& Long, 2003).

As described earlier, Cuevas et al. (2010) showed that reported psychological distress following initial abuse experiences predicted youth's revictimization within one year of initial interview. Poor psychological adjustment also predicts revictimization in adulthood (Gidycz et al., 1993), and psychological distress has been shown to mediate the relationship between CSA and adult sexual victimization (Orcutt, Cooper, \& Garcia, 2005). PTSD has also been shown to mediate and moderate the relationship between CSA and revictimization in adulthood (Arata, 2000; Messman-Moore, Brown, \& Koelsch, 2005; Sandberg, Matorin, \& Lynn, 1999). Specifically, Risser, Hetzel-Riggin, Thomsen, and McCanne (2006) found hyperarousal symptoms of PTSD to mediate revictimization in adult women and argued that these women may not be able to sense real from perceived danger, increasing their likelihood of being in and staying in risky situations. Additionally, avoidance symptoms of PTSD may mediate the relationship between CSA and subsequent victimization by decreasing awareness and the ability to detect danger, leaving victims more likely to engage in relationships with abusive partners (Chu, 1992). Fortier et al. (2009) used meditational analysis to provide further evidence that avoidant coping following the experience of CSA exacerbates trauma symptoms therefore elevating risk for revictimization.

Peterson and Seligman (1983) proposed a theory of learned helplessness in which individuals experiencing CSA develop an internal, stable, and global attributional style leading them to believe that they are the cause of their abuse, the abuse will not stop, and their lives will be permanently, negatively affected by their abuse experiences. This attributional 
style is associated with emotional numbing and passivity to the point at which individuals may submit to perpetrators rather than attempt to escape risky situations (Peterson \& Seligman, 1983). Self-blame following CSA has been associated with poorer outcomes (Frazier, 2003) and mediates the relationship between CSA and revictimization along with posttraumatic stress symptoms and risky sexual behavior (Arata, 2000; Tapia, 2014).

Both CSA and revictimization are associated with difficulties in interpersonal relationships, which is hallmark to the ecological model of development. For example, Cloitre, Scarvalone, and Difede (1997) showed that women who have experienced victimization in both childhood and adulthood indicate more difficulty in the interpersonal areas of sociability, submissiveness, intimacy, responsibility, and control. Further, despite using retrospective report, the authors showed that these effects were not primarily attributable to the experience of multiple episodes of victimization but rather mediated the relationship between CSA and revictimization in adulthood (Cloitre et al., 1997). Classen, Field, Koopman, Nevill-Manning, and Spiegel (2001) also supported this notion that revictimized women have more difficulties interpersonally. Specifically, they found the interpersonal characteristics of attributing more responsibility to the self, having difficulty with assertiveness, being socially avoidant, and being overly nurturing were associated with revictimization (Classen et al., 2001). Additionally, in response to the emotional distress that accompanies CSA, victims may employ maladaptive coping techniques such as withdrawing from others in an attempt to avoid or diminish negative thoughts and feelings (DiPalma, 1994; Oaksford \& Frude, 2003). Both a lack of skill relating to others as well as behavioral withdrawal may greatly impact interpersonal functioning, thus influencing risk for future victimization.

Those who experience CSA tend to report increased use and abuse of alcohol and illicit substances (Kotchick, Shaffer, Forehand, \& Miller, 2001; Sartor, Agrawal, McCurcheon, Duncan, \& Lynskey, 2008; Walsh et al., 2014) and having sex with anonymous partners (Kotchick et al., 2001), both of which increases subsequent risk for sexual victimization (Polusny \& Follette, 1995). Testa, Hoffman, and Livingston (2010) recently examined how risky behaviors, including sexual risk-taking and increased alcohol use, influence the relationship between adolescent and college experiences of sexual victimization. Results indicated that heavy episodic drinking partially mediated this relationship, showing that adolescent experiences of victimization increased the probability of heavy drinking, thus exacerbating the likelihood of college victimization (Testa et al., 2010). Another study by Walsh et al. (2014) bolstered these findings. More specifically, the authors found that female college students who with multiple victimization experiences were more likely to abuse substances.

Increases in sexualized behavior that often follow CSA may bear the most weight out of all the psychosocial factors discussed thus far. A breadth of studies employing adult and adolescent samples provide evidence that heightened sexualization greatly increases future risk for victimization. Exploring possible mediators of adolescent sexual revictimization, Bramsen et al. (2013) collected victimization and behavioral information from high school girls. The authors found that the relationship between CSA and adolescent victimization was fully accounted for by number of sexual partners and sexual risk behaviors, and that youth victims of CSA also experience difficulties setting sexual boundaries with 
male partners, although this did not mediate sexual revictimization (Bramsen et al., 2013). These findings build on prior evidence that sexual and overall risk-taking increase the possibility of adolescent sexual revictimization (Koss \& Dinero, 1989; Mandoki \& Burkhart, 1989; Mayall \& Gold, 1995; Simons \& Whitbeck, 1991). In regard to studies of adult populations, risky sexual behaviors are more prevalent in women who report experiencing both childhood and adult sexual victimization (Miner, Klotz Flitter, \& Robinson, 2006) and may even have the same mediating effect as has been found in adolescent samples (Fargo, 2009; Van Bruggen, Runtz, \& Kadlec, 2006. Other studies have demonstrated heightened risk for revictimization among women who engage in sexual acts with multiple partners and those who exchange in sex for money (Rinehart, Yeater, Musci, Letourneau, \& Lenberg, 2014; Ullman \& Vasquez, 2015).

\subsubsection{Abuse experiences}

Although much of the literature linking CSA and subsequent victimization dichotomizes initial abuse experiences (i.e., present and not-present), there is reason for future endeavors to account for the qualitative characteristics of CSA in helping to explain revictimization risk factors. For example, these characteristics may include frequency and duration of abuse, abuse severity, and use of force (Classen et al., 2005) as well as the recency of initial abuse (Collins, 1998; Himelein, 1995; Maker et al., 2001). Using path analysis to predict sexual revictimization of adult women, Arata (2000) found that repeated victimization was associated with more enduring and severe forms of initial abuse. Similar findings by Waldron, Wilson, Patriquin, and Scarpa (2015) suggested that more frequent abuse experiences in childhood are related to revictimization in adulthood. Swanston et al. (2002) used a longitudinal design to examine factors that promote reabuse in youth presenting to a hospital setting for allegations of sexual abuse. Reviewing official records six years after initial presentation, the authors found that severity of abuse significantly predicted subsequent victimization. Specifically, those youth who had experienced penetrative sexual abuse were at higher risk for reabuse (Swanston et al., 2002). These findings have been reinforced by more recent investigations showing strong associations between initial abuse severity and sexual revictimization (Casey \& Nurius, 2005; Simmel et al., 2012; Tapia, 2014). However, a study by Matta Oshima et al. (2014) found no relationship between abuse severity and later revictimization risk.

It may also be helpful to examine CSA experiences from a cumulative risk perspective in predicting likelihood of persistent victimization. For example, Loeb, Gaines, Wyatt, Zhang, and Liu (2011) found that summed composite scores of abuse severity helped to better explain the relationship between victimization occurrences than a simple binary measure. This summed composite included information about the specific abusive acts, the relationship of perpetrator to victim, the recency of abuse, and the victim age at abuse onset (Loeb et al., 2011).

\subsection{Microsystems}

Microsystem factors that impact risk for revictimization include contexts in which initial and subsequent abusive interactions occur. In addition, the ecological model of revictimization must take into account contexts that influence behavior of the individual in which 
abuse may not directly occur. The specific microsystems of interest include the family, peer groups, helping professionals, and the victim-perpetrator relationship.

\subsubsection{Family}

The family may be the single most important context of development. Especially in childhood and adolescence, individuals spend a significant portion of their waking hours interacting with their relatives and operating within family norms and values. Children are also highly dependent on family members for basic needs, financial and emotional support, and access to the outside world.

There are many factors stemming from within the family that may lead to entrapment in the cycle of victimization, promoting both initial and subsequent abuse experiences. For example, using structural equation modeling to examine revictimization risk, Fargo (2009) identified the childhood family environment as a significant predictor of child sexual and physical abuse. Results indicated that youth being left alone by parents, having parents that used weapons against one another or hit one another, having a mother with a mental health or drinking problem, and having lived with a variety of different caregivers were all significant risk factors for revictimization (Fargo, 2009). Kellogg and Hoffman (1997) surveyed 538 youth and young adults presenting to various clinics with focus on sexual abuse, family planning, family practice, and pregnancy/parenting. The authors found that those coming from homes in which there was violence and/or substance abuse were more likely to report unwanted sexual experiences by multiple perpetrators, thus they concluded that children from homes with these problems may be exposed to more perpetrators over time (Kellogg \& Hoffman, 1997). In their study described above, Swanston et al. (2002) found that instability in primary caregivers increased risk of subsequent abuse and neglect. In addition to the chaotic family characteristics of violence and instability, youth living within families on state assistance are at increased risk for revictimization (Matta Oshima et al., 2014). Finally, examining factors that both promote and buffer from repeated victimization, Finkelhor et al. (2007) found parental supervision and having more older siblings to protect from revictimization at their one-year follow-up; living within a violent family promoted subsequent victimization. For youth who had not been victimized at the first data collection time-point, living within a dangerous family and having more family problems predicted the emergence of victimization (Finkelhor et al., 2007).

Caregiver support is widely evidenced to promote healthy adjustment following the experience of CSA (Elliott \& Carnes, 2001). Aside from helping youth's emotional and behavioral well-being following CSA, caregiver support may be influential in a child's decision to disclose abuse (Malloy \& Lyon, 2006), which is the first step in removing them from the abusive situation and gaining access to support services. Further, there is some evidence suggesting that a lack of parental support following disclosure may influence risk of continued victimization. Examining prosecuted cases of CSA, Sas and Cunningham (1995) found that of $60 \%$ of youth whose parents did not report abuse following their child's disclosure experienced reabuse.

However, the nature of the relationship between caregiver support and revictimization remains unclear given inconsistent research findings. Examining caregiver characteristics in general (as opposed to reactions surrounding abuse discovery), Jankowski, Leitenberg, 
Henning, and Coffey (2002) surveyed adult women using self-report questionnaires and found that neither maternal nor paternal warmth and caring acted as a buffer for the increased risk of sexual revictimization in CSA survivors. Mayall and Gold (1995) found similar effects also using questionnaires to examine mediators of the CSA-revictimization relationship. At least one large-scale study has found that in comparison to women with single victimization experiences, women who have experienced multiple instances of sexual victimization report feeling that responses to their disclosures were less helpful (Casey \& Nurius, 2005).

\subsubsection{Peers}

As individuals progress from childhood through adolescence, peer influence on behavioral and emotional functioning increases dramatically. Although there is little research examining peer support following initial abuse experiences, there is evidence to support that dyadic and group peer relationships can affect both internalizing and externalizing symptomatology of youth in general (Deater-Deckard, 2001). Further, more so than adults, youth are susceptible to peer influence when deciding to engage in risky behaviors such as alcohol or substance use and unsafe sexual practices (Arnett, 1992; Chassin, Hussong, \& Beltran, 2009 and research is beginning to explore biological mechanisms underlying peer influence on adolescents. For example, Chein, Albert, Brien, Uckert, and Steinberg (2012) used fMRI during a laboratory risk-taking paradigm and found that, for adolescents only, being observed by a peer resulted in greater activation of the brain's reward systems. In sum, not only are children and adolescents more likely to engage in risky behaviors compared to adults (Boyer, 2006), they are more susceptible to peer influence in making these risky decisions. Add the danger that follows risk taking - for example, heightened risk of experiencing rape or attempted rape for those who engage in binge drinking (Champion et al., 2004)-and we are left with a developmental context in desperate need of further examination.

On the other hand, peers may exert positive influence by providing social support during times of need. For example, looking at revictimization in an adult sample, Bender, Cook, and Kaslow (2003) found social support to partially mediate the relationship between child sexual abuse and physical intimate partner violence. Additionally, social support fully mediated the relationship between child sexual abuse and emotional partner violence. Following adolescent mothers for one year, Collins (1998) found satisfaction with social relationships to reduce revictimization risk.

\subsubsection{Professionals}

The impact of receiving treatment from a helping professional, such as a therapist, after the experience of sexual abuse is unclear regarding risk for revictimization. Therapeutic support may buffer the risk for repeat victimization (Mayall \& Gold, 1995); however, some sexual revictimization prevention programs have failed to show reduction in risk (Breitenbecher \& Gidycz, 1998; Hanson \& Gidycz, 1993). The Youth Relationships Manual (Wolfe et al., 1996), an 18-session intervention based on skills-enhancement that draws upon fem-

inist theories of societal norms for females, is one approach for reducing risk for dating violence in adolescents with child maltreatment histories. In an evaluation of this program, 
Wolfe et al. (2003) found that intervention led to reductions in participants' report of emotional abuse and threatening behavior within intimate partner relationships. This unique sample included males and females, indicating differential impact on report of physical abuse within romantic relationships; males exhibited better treatment gains compared to female intervention participants. Marx, Calhoun, Wilson, and Meyerson (2001) employed a brief intervention design to enhance risk detection skills in adult women with histories of adolescent or adult sexual assault. The two-day intervention-focused on offender characteristics, common reactions to assault, risk recognition and response, problem-solving skills, assertiveness, and communication skills-resulted in less report of rape in the two months following intervention for those who participated in treatment sessions versus nointervention controls (Marx et al., 2001). Combatting the harmful effects of avoidance, Hill, Vernig, Lee, Brown, and Orsillo (2011) developed a mindfulness and acceptance-based intervention to reduce adult sexual assault in college women with histories of CSA. Although women who received the intervention were less likely to experience rape during the followup period, the effect was nonsignificant.

Recently, DePrince, Chu, Labus, Shirk, and Potter (2015) compared Wolfe et al. (1996) feminist intervention with an adapted version of the risk detection intervention designed by Marx et al. (2001), evaluating their impact on likelihood of subsequent sexual victimization. Using these programs with adolescent girls in the child welfare system, the authors found that youth not receiving either of the prevention programs reported higher rates of sexual revictimization than those receiving the feminist approach (DePrince et al., 2015).

\subsubsection{Perpetrators}

As with many other contextual factors, the influence of one's relationship to the initial abuse perpetrator on subsequent victimization remains unclear. Few investigations have examined how relationship to CSA perpetrators might increase or decrease risk for revictimization, and the results have been inconsistent. In their longitudinal study, Matta Oshima et al. (2014) found that having a male perpetrator and experiencing abuse by a parent's significant other increased risk for subsequent victimization. Drake, Jonson-Reid, Way, and Chung (2003) reviewed case records of youth and families who had been involved with the Missouri Division of Family Services for an initial report of abuse or neglect between 1993 and 1994. Examining 4,681 cases of sexual abuse, they found no significant difference between parent and nonparent perpetrators on likelihood of having a re-report. Classen and colleagues also note the dearth of information regarding perpetrator characteristics in their 2005 review of sexual revictimization literature. They state that at least one study has shown intrafamilial CSA to increase risk of victimization in adulthood (Kessler \& Bieschke, 1999), while other investigations have returned null results.

When examining revictimization, it is important to consider the perpetrator's role in subsequent assaultive episodes. Grauerholz (2000) provides a thorough discussion of this in her review, stating that vulnerability for revictimization may be influenced by an increased likelihood that a perpetrator will act aggressively toward that specific individual. Specifically, she notes that "there are other factors also at work that serve to increase the likelihood that men will perceive women as easy targets or perceive situations as ones in which their sexually aggressive attempts will be successful" (Grauerholz, 2000, p. 11). Rossmo (1997, 2000) 
and Beauregard, Rossmo, and Proulx (2007) describe the hunting processes used by sex offenders in great detail, noting both perpetrator and victim behaviors that influence victim selection. Following availability (i.e., proximity to and access by perpetrator), perpetrators take into account potential victims' physical appearance, vulnerability, age, personality, and behavior (Rebocho \& Silva, 2014). Thus, there is interplay between the individual and potential perpetrator that may increase the risk of a victimization occurrence, and examining perpetrator hunting behaviors may help clarify this interaction.

\subsection{Mesosystems}

Although Belsky (1980) did not address mesosystems in his etiological model of child maltreatment, focusing on this contextual level has potential to greatly contribute to our understanding of revictimization. As stated above, mesosystems represent the interaction of any two microsystems for a given individual. For example, some important mesosystems for youth may include the interactions between parents and schools, peers and family members, or helping professionals and family members. Unfortunately, examination of these systems is missing from the revictimization literature, likely due to the difficulty of gathering information from sources outside of the family for research purposes. In their review, Kotchick et al. (2001) recommend taking a multisystem perspective to adolescent sexual risk behaviors, noting reciprocal influence of family, peers, and self. Parental interaction with peer groups occurs largely through monitoring behaviors (i.e., requesting names, addresses, and phone numbers of peers; building rapport with peers and their parents; check-ins while youth are out of the home, etc.) and youth whose parents consistently monitor their social interactions engage in less sexual activity (Romer et al., 1994).

Another interesting mesosystem involves parents and the child welfare system. Youth in the child welfare system, particularly those in foster care, are at higher risk for revictimization than their peers (DePrince et al., 2015). In order to relinquish child welfare involvement, parents often have to comply with recommendations and exhibit their ability to provide a safe environment for their children. Therefore, parents who are incapable of complying with child welfare mandates or recommendations may place their children at heightened risk for subsequent victimization by prolonging involvement with the child welfare system.

\subsection{Exosystems}

As stated in the descriptions of both Bronfenbrenner's and Belsky's models, exosystems refer to those contexts in which the developing individual may not immediately interact but that influence more proximal contexts of development (i.e., microsystems). Considering sexual abuse and continued victimization, these contexts are likely to include one's community/neighborhood and the legal system implemented by those communities.

\subsubsection{Neighborhood factors}

Evidence is mounting to show that youth from neighborhoods with certain unfavorable characteristics may be at higher risk for a number of negative outcomes, among them victimization of many forms. Coulton, Crampton, Irwin, Spilsbury, and Korbin (2007) reviewed 25 studies of the link between neighborhood characteristics and child maltreatment, concluding 
that there is a strong association between these constructs. Specific to sexual abuse, neighborhoods with fewer economic and social resources tended to have higher rates of maltreatment reports (Drake \& Pandey, 1996; Ernst, 2000). These neighborhoods may also impact child adjustment following maltreatment, with those in suboptimal environments experiencing more psychological problems (Jaffee, Caspi, Moffitt, Polo-Tomas, \& Taylor, 2007).

Regarding continued risk for victimization, a recent investigation showed that youth who moved into neighborhoods they perceived as "worse" in comparison to others were more likely to be persistent victims (Finkelhor et al., 2007). Additionally, Drake et al. (2003) found that sexually abused youth living in neighborhoods with low median incomes (i.e., less than $\$ 20,000$ per year) had higher rates of reabuse than those living in higher income neighborhoods. Although they did not specifically explore sexual revictimization, Obasaju, Palin, Jacobs, Anderson, and Kaslow (2009) showed that perceived neighborhood disorder and community cohesion moderated the relationship between childhood abuse and experiencing intimate partner violence in adulthood.

\subsubsection{Legal and judicial responses to abuse}

The Child Advocacy Center (CAC) model was developed in part to reduce psychological trauma to children caused by multiple invasive interviews (Anderson \& McMaken, 1990). As such, it is expected that investigations occurring within this model may impact child functioning following abuse disclosure; however, few studies have examined how investigative and judicial processes influence risk for continued victimization. Examining the impact of case substantiation vs. unsubstantiation, Drake et al. (2003) found substantiation to be associated with higher rates of abuse re-report for youth experiencing physical abuse and neglect although this effect was not significant for sexual abuse. Nor was substantiation associated with the absence of additional abuse reports (Drake et al., 2003). Wolfteich and Loggins (2007) sought to evaluate how the CAC model specifically impacts revictimization of sexually abused youth. The authors found that cases investigated through the CAC model had a higher case substantiation rate in comparison to two other child maltreatment investigation models, although there were no differences in rates of revictimization (Wolfteich \& Loggins, 2007). There appear to be some advantages to the current model of child abuse investigation; however, little is known about its impact on the cycle of victimization.

\subsection{Macrosystems}

Macrosystems refer to the overarching beliefs and values of the culture(s) within which the developing individual exists that permeate the other, more proximal systems. Given their abstract nature, factors at the macrosystem level may be some of the most difficult constructs to empirically test in regard to specific developmental outcomes. As such, there is little evidence to examine regarding the role of macrosystems in promoting or protecting from revictimization. In her theoretical integration of sexual revictimization research, Grauerholz (2000) calls attention to the broader societal values of emphasizing traditional gender roles and promoting prejudiced views of sexual assault victims in how they might lead to repeat victimization. She identifies victim-blaming attitudes as culprits in promoting 
revictimization, citing that notions of "good girl" versus "bad girl" and society's value of sexual virtue for women encourage suspicion of those who have experienced sexual abuse or assault (Grauerholz, 2000). While these factors are far removed from the individual, they surely impact perceptions of support as well as victims' feelings of guilt and shame following abuse.

More concrete examples of this contextual level include federal policy regarding child maltreatment and governing bodies that oversee entities that serve child victims. The Federal Child Abuse Prevention and Treatment Act (CAPTA, 1974) as amended by the CAPTA Reauthorization Act of 2010, for example, describes a coordinated response to child abuse and neglect, requiring the child protection system to prevent recurrence of abuse through federal and state mechanisms designed to support children and families. This Act, although devised in a context far removed from the individual, provides the legislation that may fund programs with which the individual interacts, namely prevention programs that aim to keep children safe.

The National Children's Alliance (NCA) is another exosystem factor that influences the individual through policies and procedures set forth by CACs. NCA is the national association and accrediting body for CACs and thus is important in advocating for victims' rights and services at the macrolevel. Societal and cultural values dictate to some degree what policies are enacted to protect children, thus examining the impact of policy changes on revictimization may be a promising method to gain insight into the impact of these distal systems.

\subsection{Interactions across systems}

Finally, any ecological model must take into consideration the influence of factors within and between systems. Bronfenbrenner captured this notion, summarizing that human existence is so complex that in order to understand etiology we must first identify and then account for all factors at play. Belsky (1980) reiterated this by emphasizing the importance of examining "nested relationships that exist between causative agents" (p. 321). The notion that systems interact in regard to revictimization is present in the work of many researchers attempting to develop path models that follow individuals from initial to subsequent victimization episodes.

Although many research efforts have focused solely on factors within the individual, at the ontogenic development level (e.g., Bramsen et al., 2013; Orcutt et al., 2005; Testa et al., 2010; Van Bruggen et al., 2006), Arata (2000) and Fargo (2009) executed two notable studies including multiple contexts of development. In her revictimization model, Arata (2000) hypothesized that characteristics of the initial abuse experience, including the relationship of perpetrator to victim, would influence the development of emotional and behavioral symptoms, leading to a higher likelihood of revictimization. While many factors were examined from the individual level, inclusion of relationship to perpetrator extends the model to the microsystem as well. In the final model, however, only ontogenic development factors (i.e., self-blame, posttraumatic stress symptoms, sexual behaviors) were significantly associated with sexual revictimization. Fargo's (2009) model of revictimization

accounted for negative childhood environment as influencing initial abuse experiences and the development of behaviors that place adolescents at higher risk for subsequent 
victimization. As described in section 4.2.1, Fargo's model identified multiple environmental risk factors that influence risk for revictimization thus providing empirical support that ecological contexts beyond the individual matter. For example, being poorly monitored and living in homes with domestic violence and/or parental mental health or alcohol problems increased revictimization risk.

\section{Recommendations for research and practice}

Sexual revictimization of youth is a public health concern as it occurs frequently and is associated with negative outcomes, including psychological and behavioral sequelae as well as additional victimization. Although most research has focused on the link between CSA and adult sexual assault, evidence urges a conceptual shift so that we begin to view revictimization as a cycle of violence that impacts individuals across developmental stages. This notion is supported by the downward spiral described by Miron and Orcutt (2014) whereby CSA influences risk for adolescent sexual assault which in turn increases risk for adult sexual assault. To aid in forging this shift, the following recommendations for research and practice are provided. First, the field must adopt a guiding framework to direct research and intervention endeavors (Macy, 2007; Messman-Moore \& Long, 2003). Bronfenbrenner's bioecological model seems apt to fulfill this need by allowing focus on the many contexts within which individuals operate throughout the lifespan. Employing this model will not only allow for unification across the field, but will help minimize victim blaming by accounting for factors external to the individual (Grauerholz, 2000). In particular, the field would benefit from further examination of microsystems, such as the family and peer groups, regarding risk for additional victimization, and exosystems, including public policy regarding child welfare.

Second, future research endeavors should contribute to the small but growing body of literature addressing the cycle of victimization within childhood and adolescence. At present, there is evidence that youth who experience initial victimization at or before preadolescence are more likely to be revictimized (Casey \& Nurius, 2005; Humphrey \& White, 2000; Simmel et al., 2012), as are those with greater distress following initial abuse (Cuevas et al., 2010) and those who engage in sexual risk taking (Bramsen et al., 2013; Koss \& Dinero, 1989; Mandoki \& Burkhart, 1989; Simons \& Whitbeck, 1991). Further investigating revictimization of youth will help bridge the gap that currently exists between adult and child/adolescent literature, ultimately serving to provide a clear picture of the cycle of victimization across the lifespan. Additionally, although there are well-developed treatments for psychological symptoms and sexual behavior problems in child sexual abuse victims, little has been said of treatment effects on risk for subsequent victimization. As such, more effort should be focused on evaluating the preventive quality of interventions designed for and widely disseminated to these youth.

Third, we recommend that all CACs consider employing mental health professionals to provide onsite assessment and intervention for youth and families. These professionals can assess for the psychological symptoms and contextual factors that influence risk for revictimization and either provide brief intervention or referral to other providers while serving in a case-managing role (Jones \& Walsh, 2010). Oftentimes, in cases of child physical abuse 
or neglect, entities external to the family become involved for monitoring reasons (i.e., Department of Health and Human Services); however, this occurs less frequently in cases of sexual abuse. Parents may not be deemed to need monitoring in order to keep their children safe in the immediacy, although brief intervention and assessment may help families access support, potentially protecting youth in the long-term.

This review provides an update on the literature regarding sexual revictimization of youth as well as a possible framework for guiding future research endeavors. Recognition of revictimization within childhood and adolescence has spurred investigation during these developmental periods although gaps still exist regarding differential risk for youth and adults as well as points of intervention and prevention to protect victims of sexual violence. Given the complexities of human development and the well-established heterogeneous responses to sexual violence (Putnam, 2003), Bronfenbrenner's model provides helpful guidance for conceptualizing and examining victimization and revictimization. Operating within this framework will help address gaps in research evidence and inform intervention and prevention programs.

\section{References}

Anderson, A.F., \& McMaken, M.E. (1990). Implementing child advocacy: A rationale and basic blueprint. Juvenile and Family Court Journal, 41, 1-14. http://dx.doi.org/10.1111/j.1755-6988.1990 .tb00669.x.

Arata, C.M. (2000). From child victim to adult victim: A model for predicting sexual revictimization. Child Maltreatment, 5, 28-38. http://dx.doi.org/10.1177/1077559500005001004.

Arata, C.M. (2002). Child sexual abuse and sexual revictimization. Clinical Psychology: Science and Practice, 9, 135-164. http://dx.doi.org/10.1093/clipsy.9.2.135.

Arnett, J. (1992). Reckless behavior in adolescence: A developmental perspective. Developmental Review, 12, 339-373. http://dx.doi.org/10.1016/0273-2297(92)90013-R.

Balsam, K.F., Lehavot, K., \& Beadnell, B. (2011). Sexual revictimization and mental health: A comparison of lesbians, gay men, and heterosexual women. Journal of Interpersonal Violence, 26, 17981814. http://dx.doi.org/10.1177/0886260510372946.

Banyard, V.L., Williams, L.M., \& Siegel, J.A. (2001). The long-term mental health consequences of child sexual abuse: An exploratory study of the impact of multiple traumas in a sample of women. Journal of Traumatic Stress, 14, 697-715. http://dx. doi.org/10.1023/A:1013085904337.

Barnes, J.E., Noll, J.G., Putnam, F.W., \& Trickett, P.K. (2009). Sexual and physical revictimization among victims of severe childhood sexual abuse. Child Abuse \& Neglect, 33, 412-420. http://dx.doi.org/10.1016/j.chiabu.2008.09.013.

Beauregard, R., Rossmo, K., \& Proulx, J. (2007). A descriptive model of the hunting process of serial sex offenders: A rational choice perspective. Journal of Family Violence, 22, 449-463. http://dx.doi.org/10.1007/s10896-007-9101-3.

Belsky, J. (1980). Child maltreatment: An ecological integration. American Psychologist, 35, 320-355. http://dx.doi.org/10.1037//0003-066X.35.4.320.

Belsky, J. (1989). Child maltreatment: An ecological integration. American Psychologist, 35, 320-335. http://dx.doi.org/10.1016/0145-2134(94)00042-5.

Belsky, J. (1993). Etiology of child maltreatment: A developmental-ecological analysis. Psychological Bulletin, 114, 413-434. http://dx.doi.org/10.1037/0033-2909.114.3.413. 
Bender, M., Cook, S., \& Kaslow, N. (2003). Social support as a mediator of revictimization of lowincome African American women. Violence and Victims, 18, 419-431. Retrieved from http://www .ncbi.nlm.nih.gov/pubmed/14582863.

Boney-McCoy, S., \& Finkelhor, D. (1995). Psychosocial sequelae of violent victimization in a national youth sample. Journal of Consulting and Clinical Psychology, 63, 726-736. http://dx.doi.org/10.1037// 0022-006X.63.5.726.

Boyer, T.W. (2006). The development of risk-taking: A multi-perspective review. Developmental Review, 26, 291-345. http://dx.doi.org/10.1016/j.dr.2006.05.002.

Bramsen, R.H., Lasgaard, M., Koss, M.P., Shevlin, M., Elklit, A., \& Banner, J. (2013). Testing a multiple mediator model of the effect of childhood sexual abuse on adolescent sexual victimization. American Journal of Orthopsychiatry, 83, 47-54. http://dx.doi.org/10.1111/ajop.12011.

Breitenbecher, K.H. (1999). The association between the perception of threat in a dating situation and sexual victimization. Violence and Victims, 14, 135-146.

Breitenbecher, K.H., \& Gidycz, C.A. (1998). An empirical evaluation of a program designed to reduce the risk of multiple sexual victimization. Journal of Interpersonal Violence, 13, 471-488. http://dx .doi.org/10.1177/088626098013004004.

Bronfenbrenner, U. (1977). Toward an experimental ecology of human development. American Psychologist, 32, 513-531. http://dx.doi.org/10.1037//0003-066X.32.7.513.

Bronfenbrenner, U. (1994). Ecological models of human development (2nd ed.). International Encyclopedia of Education, 3. Oxford, UK: Elsevier.

Bronfenbrenner, U., \& Ceci, S.J. (1994). Nature-nurture reconceptualized in developmental perspective: a bioecological model. Psychological Review, 101, 568-586. http://dx.doi.org/10.1037/0033295X.101.4.568.

Casey, E.A., \& Nurius, P.S. (2005). Trauma exposure and sexual revictimization risk: Comparisons across single, multiple incident, and multiple perpetrator victimizations. Violence Against Women, 11, 505-530. http://dx.doi.org/10.1177/1077801204274339.

Champion, H.I.O., Foley, K.L., DuRant, R.H., Hensberry, R., Altman, D., \& Wolfson, M. (2004). Adolescent sexual victimization, use of alcohol and other substances, and other health risk behaviors. Journal of Adolescent Health, 35, 321-328. http://dx.doi.org/10.1016/j.jadohealth.2003.09.023.

Chassin, L., Hussong, A., \& Beltran, I. (2009). In R. Lerner, \& L. Steinberg (Eds.), Adolescent substance use. Handbook of adolescent psychology, 1. (pp. 723-763). Hoboken, NJ: Wiley.

Chein, J., Albert, D., Brien, L.O., Uckert, K., \& Steinberg, L. (2012). Peers increase adolescent risk taking by enhancing activity in the brain's reward circuitry. Developmental Science, 14(2), 1-16. http://dx.doi.org/10.1111/j.1467-7687.2010.01035.x.Peers.

Child Abuse Prevention and Treatment Act, 42 U.S.C.A. $\S 5106 \mathrm{~g}(1974)$.

Chu, J.A. (1992). The revictimization of adult women with histories of childhood abuse. Journal of Psychotherapy Practice and Research, 1, 259-269.

Cicchetti, D., \& Banny, A. (2014). A developmental psychopathology perspective on child maltreatment. In M. Lewis, \& K.D. Rudolph (Eds.), Handbook of developmental psychopathology (pp. 723741). New York, NY: Springer. http://dx.doi.org/10.1007/978-1-4614-9608-3_37.

Classen, C.C., Palesh, O.G., \& Aggarwal, R. (2005). Sexual revictimization: A review of the empirical literature. Trauma, Violence, \& Abuse, 6, 103-129. http://dx.doi.org/10.1177/1524838005275087.

Classen, C., Field, N.P., Koopman, C., Nevill-Manning, K., \& Spiegel, D. (2001). Interpersonal problems and their relationship to sexual revictimization among women sexually abused in childhood. Journal of Interpersonal Violence, 16, 495-509. http://dx.doi.org/10.1177/088626001016006001. 
Cloitre, M., Scarvalone, P., \& Difede, J. (1997). Posttraumatic stress disorder, self and interpersonal dysfunction among sexually retraumatized women. Journal of Traumatic Stress, 10, 437-452. http://dx.doi.org/10.1002/jts.2490100309.

Coid, J., Petruckevitch, A., Feder, G., Chung, W.S., Richardson, J., \& Moorey, S. (2001). Relation between childhood sexual and physical abuse and risk of revictimisation in women: A cross-sectional survey. The Lancet, 358, 450-454. http://dx.doi.org/10.1016/S0140-6736(01)05622-7.

Collins, M.E. (1998). Factors influencing sexual victimization and revictimization in a sample of adolescent mothers. Journal of Interpersonal Violence, 13, 3-24. http://dx.doi.org/10.1177/08862609801 3001001.

Coulton, C.J., Crampton, D.S., Irwin, M., Spilsbury, J.C., \& Korbin, J.E. (2007). How neighborhoods influence child maltreatment: A review of the literature and alternative pathways. Child Abuse $\mathcal{E}$ Neglect, 31, 1117-1142. http://dx.doi.org/10.1016/j.chiabu.2007.03.023.

Crowley, S. (2000). The search for autonomous intimacy: Sexual abuse and young women's identity development. New York, NY: Peter Lang.

Cuevas, C.A., Finkelhor, D., Clifford, C., Ormrod, R.K., \& Turner, H.A. (2010). Psychological distress as a risk factor for re-victimization in children. Child Abuse \& Neglect, 34, 235-243. http://dx.doi .org/10.1016/j.chiabu.2009.07.004.

De Bellis, M., Spratt, E., \& Hooper, S. (2011). Neurodevelopmental biology associated with childhood sexual abuse. Journal of Child Sexual Abuse, 20, 548-587. http://dx.doi.org/10.1080/10538712.2011 .607753 .

Deater-Deckard, K. (2001). Annotation: Recent research examining the role of peer relationships in the development of psychopathology. Journal of Psychology and Psychiatry, 42, 565-579. http://dx .doi.org/10.1111/1469-7610.00753.

DePrince, A.P., Chu, A.T., Labus, J., Shirk, S.R., \& Potter, C. (2015). Testing two approaches to revictimization prevention among adolescent girls in the child welfare system. Journal of Adolescent Health, 56, 533-539. http://dx.doi.org/10.1016/j.jadohealth.2014.06.022.

Desai, S., Arias, I., Thompson, M.P., \& Basile, K.C. (2002). Childhood victimization and subsequent adult revictimization assessed in a nationally representative sample of women and men. Violence and Victims, 17, 639-653. http://dx.doi.org/10.1891/vivi.17.6.639.33725.

DiPalma, L.M. (1994). Patterns of coping and characteristics of high-functioning incest survivors. Archives of Psychiatric Nursing, 8, 82-90. http://dx.doi.org/10.1016/0883-9417(94)90038-8.

Drake, B., \& Pandey, S. (1996). Understanding the relationship between neighborhood poverty and specific types of child maltreatment. Child Abuse \& Neglect, 20, 1003-1018. http://dx.doi.org/10 .1016/0145-2134(96)00091-9.

Drake, B., Jonson-Reid, M., Way, I., \& Chung, S. (2003). Substantiation and recidivism. Child Maltreatment, 8, 248-260. http://dx.doi.org/10.1177/1077559503258930.

Elliott, A.N., \& Carnes, C.N. (2001). Reaction of nonoffending parents to the sexual abuse of their child: A review of the literature. Child Maltreatment, 6, 314-331. http://dx.doi.org/10.1177/1077559 501006004005.

Elliott, D.M., \& Briere, J. (1992). Sexual abuse trauma among professional women: Validating the Trauma Symptom Checklist-40 (TSC-40). Child Abuse \& Neglect, 16, 391-398. http://dx.doi.org/10 .1016/0145-2134(92)90048-V.

Ernst, J.S. (2000). Mapping child maltreatment: Looking at neighborhoods in a suburban county. Child Welfare, 79, 555-572. 
Fargo, J.D. (2009). Pathways to adult sexual revictimization: Direct and indirect behavioral risk factors across the lifespan. Journal of Interpersonal Violence, 24, 1771-1791. http://dx.doi.org/10.1177/ 0886260508325489 .

Fergusson, D.M., Horwood, L.J., \& Lynskey, M.T. (1997). Childhood sexual abuse, adolescent sexual behaviors and sexual revictimization. Child Abuse \& Neglect, 21, 789-803. http://dx.doi.org/10 .1016/S0145-2134(97)00039-2.

Finkelhor, D., Ormrod, R.K., \& Turner, H.A. (2007). Re-victimization patterns in a national longitudinal sample of children and youth. Child Abuse \& Neglect, 31, 479-502. http://dx.doi.org/10.1016/ j.chiabu.2006.03.012.

Fortier, M.A., DiLillo, D., Messman-Moore, T.L., Peugh, J., DeNardi, K.A., \& Gaffey, K.J. (2009). Severity of child sexual abuse and revictimization: The mediating role of coping and trauma symptoms. Psychology of Women Quarterly, 33, 308-320. http://dx.doi.org/10.1111/j.1471-6402.2009 .01503.x.

Frazier, P.A. (2003). Perceived control and distress following sexual assault: A longitudinal test of a new model. Journal of Personality and Social Psychology, 84, 1257-1269. http://dx.doi.org/10.1037/ 0022-3514.84.6.1257.

Friedenberg, S.L., Hansen, D.J., \& Flood, M.F. (2013). Epidemiology of child and adolescent sexual abuse. In D.S. Bromberg, \& W.T. O'Donohue (Eds.), Handbook of child and adolescent sexuality: Developmental and forensic psychology (pp. 303-324). Oxford, UK: Elsevier. http://dx.doi.org/10.1016/ B978-0-12-387759-8.00012-X.

Gidycz, C.A., Coble, C.N., Latham, L., \& Layman, M.J. (1993). Sexual assault experience in adulthood and prior victimization experiences. Psychology of Women Quarterly, 17, 151-168. http://dx.doi .org/10.1111/j.1471-6402.1993.tb00441.x.

Gidycz, C.A., Hanson, K., \& Layman, M.J. (1995). A prospective analysis of the relationships among sexual assault experiences: An extension of previous findings. Psychology of Women Quarterly, 19, 5-29. http://dx.doi.org/10.1111/j.1471-6402.1995.tb00276.x.

Grauerholz, L. (2000). An ecological approach to understanding sexual revictimization: Linking personal, interpersonal, and sociocultural factors and processes. Child Maltreatment, 5, 5-17. http://dx .doi.org/10.1177/1077559500005001002.

Green, B.L., Goodman, L.A., Krupnick, J.L., Corcoran, C.B., Petty, R.M., Stockton, P., \& Stern, N.M. (2000). Outcomes of single versus multiple trauma exposure in a screening sample. Journal of Traumatic Stress, 13, 271-286. http://dx.doi.org/10.1023/A:1007758711939.

Hanson, K.A., \& Gidycz, C.A. (1993). Evaluation of a sexual assault prevention program. Journal of Consulting and Clinical Psychology, 61, 1046-1052. http://dx.doi.org/10.1037/0022-006X.61.6.1046.

Heise, L. (1998). Violence against women: An integrated, ecological framework. Violence Against Women, 4, 262-290. http://dx.doi.org/10.1177/1077801298004003002.

Hill, J.M., Vernig, P.M., Lee, J.K., Brown, C., \& Orsillo, S.M. (2011). The development of a brief acceptance and mindfulness-based program aimed at reducing sexual revictimization among college women with a history of childhood sexual abuse. Journal of Clinical Psychology, 67, 969-981. http://dx.doi.org/10.1002/jclp.20813.

Himelein,M.J. (1995). Risk factors for sexual victimization in dating: A longitudinal study of college women. Psychology of Women Quarterly, 19, 31-48. http://dx.doi.org/10.1111/j.1471-6402.1995.tb00277.x.

Humphrey, J.A., \& White, J.W. (2000).Women's vulnerability to sexual assault from adolescence to young adulthood. Journal of Adolescent Health, 27, 419-424. http://dx.doi.org/10.1016/S1054139X(00)00168-3. 
Jaffee, S.R., Caspi, A., Moffitt, T.E., Polo-Tomas, M., \& Taylor, A. (2007). Individual, family, and neighborhood factors distinguish resilient from non-resilient maltreated children: A cumulative stressors model. Child Abuse \& Neglect, 31, 231-253. http://dx.doi.org/10.1016/j.chiabu.2006.03.011.

Jankowski, M.K., Leitenberg, H., Henning, K., \& Coffey, P. (2002). Parental caring as a possible buffer against sexual revictimization in young adult survivors of child sexual abuse. Journal of Traumatic Stress, 15, 235-244. http://dx.doi.org/10.1023/A:1015259412746.

Jones, L.M., \& Walsh, W.A. (2010). Improving access to mental health services for abused children in NH: System recommendations for CACs (summary report). Durham, NH: Crimes Against Children Research Center, University of New Hampshire.

Kalof, L. (2000). Ethnic differences in female sexual victimization. Sexuality and Culture, 4, 75-98. http://dx.doi.org/10.1007/s12119-000-1005-9.

Kellogg, N.D., \& Hoffman, T.J. (1997). Child sexual revictimization by multiple perpetrators. Child Abuse \& Neglect, 21, 953-964. http://dx.doi.org/10.1016/S0145-2134(97)00056-2.

Kessler, B.L., \& Bieschke, K.J. (1999). A retrospective analysis of shame, dissociation, and adult victimization in survivors of child sexual abuse. Journal of Counseling Psychology, 46, 335-341.

Koss, M.P., \& Dinero, T.E. (1989). Discriminant analysis of risk factors for sexual victimization among a national sample of college women. Journal of Consulting and Clinical Psychology, 57, 242-250. http://dx.doi.org/10.1037//0022-006X.57.2.242.

Kotchick, B.A., Shaffer, A., Forehand, R., \& Miller, K.S. (2001). Adolescent sexual risk behavior: A multi-system perspective. Clinical Psychology Review, 21, 493-519.

Krahe, B., Scheinberger-Olwig, R., Waizenhöfer, E., \& Kolpin, S. (1999). Childhood sexual abuse and revictimization in adolescence. Child Abuse \& Neglect, 23, 383-394. http://dx.doi.org/10.1016/S01452134(99)00002-2.

Loeb, T.B., Gaines, T., Wyatt, G.E., Zhang, M., \& Liu, H. (2011). Associations between child sexual abuse and negative sexual experiences and revictimization among women: Does measuring severity matter? Child Abuse \& Neglect, 35, 946-955. http://dx.doi.org/10.1016/j.chiabu.2011.06.003.

Macy, R.J. (2007). A coping theory framework toward preventing sexual revictimization. Aggression and Violent Behavior, 12, 177-192. http://dx.doi.org/10.1016/j.avb.2006.09.002.

Maker, A.H., Kemmelmeier, M., \& Peterson, C. (2001). Child sexual abuse, peer sexual abuse, and sexual assault in adulthood: A multi-risk model of revictimization. Journal of Traumatic Stress, 14, 351-368. http://dx.doi.org/10.1023/A:1011173103684.

Malloy, L., \& Lyon, T.D. (2006). Caregiver support and child sexual abuse: Why does it matter? Journal of Child Sexual Abuse, 15, 97-103. http://dx.doi.org/10.1300/J070v15n04_06.

Mandoki, C., \& Burkhart, B. (1989). Sexual victimization: Is there a vicious cycle? Violence and Victims, 4, 179-190.

Marx, B.P., Calhoun, K.S., Wilson, A.E., \& Meyerson, L.A. (2001). Sexual revictimization prevention: An outcome evaluation. Journal of Consulting and Clinical Psychology, 69, 25-32. http://dx.doi.org/ 10.1037//0022-006x.69.1.25.

Matta Oshima, K.M., Jonson-Reid, M., \& Seay, K.D. (2014). The influence of childhood sexual abuse on adolescent outcomes: The roles of gender, poverty, and revictimization. Journal of Child Sexual Abuse, 23, 367-386. http://dx.doi.org/10.1080/10538712.2014.896845.

Mayall, A., \& Gold, S.R. (1995). Definitional issues and mediating variables in the sexual revictimization of women sexually abused as children. Journal of Interpersonal Violence, 10, 26-42. http://dx.doi .org/10.1177/088626095010001002. 
Messman, T.L., \& Long, P.J. (1996). Child sexual abuse and its relationship to revictimization in adult women: A review. Clinical Psychology Review, 16, 397-420. http://dx.doi.org/10.1016/0272-7358(96) 00019-0.

Messman-Moore, T.L., \& Long, P.J. (2003). The role of childhood sexual abuse sequelae in the sexual revictimization ofwomen: An empirical reviewand theoretical reformulation. Clinical Psychology Review, 23, 537-571. http://dx.doi.org/10.1016/S0272-7358(02)00203-9.

Messman-Moore, T.L., Brown, A.L., \& Koelsch, L.E. (2005). Posttraumatic symptoms and self-dysfunction as consequences and predictors of sexual revictimization. Journal of Traumatic Stress, 18, 253-261. http://dx.doi.org/10.1002/jts.20023.

Miner, M.H., Klotz Flitter, J.M., \& Robinson, B.B.E. (2006). Association of sexual revictimization with sexuality and psychological function. Journal of Interpersonal Violence, 21, 503-524. http://dx.doi.org/ $10.1177 / 0886260505285913$.

Miron, L.R., \& Orcutt, H.K. (2014). Pathways from childhood abuse to prospective revictimization: Depression, sex to reduce negative affect, and forecasted sexual behavior. Child Abuse \& Neglect, 38, 1848-1859. http://dx.doi.org/10.1016/j.chiabu.2014.10.004.

Mullen, P.E., Martin, J.L., Anderson, J.C., Romans, S.E., \& Herbison, G.P. (1994). The effect of child sexual abuse on social, interpersonal, and sexual functioning in adult life. British Journal of Psychiatry, 165, 35-47. http://dx.doi.org/10.1192/bjp.165.1.35.

Noll, J.G., Trickett, P.K., \& Putnam, F.W. (2003). A prospective investigation of the impact of childhood sexual abuse on the development of sexuality. Journal of Consulting and Clinical Psychology, 71, 575-586. http://dx.doi.org/10.1037/0022-006X.71.3.575.

Oaksford, K., \& Frude, N. (2003). The process of coping following child sexual abuse: A qualitative study. Journal of Child Sexual Abuse, 12, 41-72. http://dx.doi.org/10.1300/J070v12n02_03.

Obasaju, M.A., Palin, F.L., Jacobs, C., Anderson, P., \& Kaslow, N.J. (2009).Won't you be my neighbor? Using an ecological approach to examine the impact of community on revictimization. Journal of Interpersonal Violence, 24, 38-53. http://dx.doi.org/10.1177/0886260508314933.

Orcutt, H.K., Cooper, M.L., \& Garcia, M. (2005). Use of sexual intercourse to reduce negative affect as a prospective mediator of sexual revictimization. Journal of Traumatic Stress, 18, 729-739. http://dx.doi.org/10.1002/jts.20081.

Peterson, C., \& Seligman, M.E.P. (1983). Learned helplessness and victimization. Journal of Social Issues, 39, 103-116. http://dx.doi.org/10.1111/j.1540-4560.1983.tb00143.x.

Polusny, M.A., \& Follette, V.M. (1995). Long-term correlates of child sexual abuse: Theory and review of the empirical literature. Applied and Preventive Psychology, 4, 143-166. http://dx.doi.org/10.1016/ S0962-1849(05)80055-1.

Putnam, F.W. (2003). Ten-year research update review: Child sexual abuse. Journal of theAmerican Academy of Child and Adolescent Psychiatry, 42, 269-278. http://dx.doi.org/10.1097/00004583200303000-00006.

Rebocho, M.F., \& Silva, P. (2014). Target selection in rapists: The role of environmental and contextual factors. Aggression and Violent Behavior, 19, 42-49. http://dx.doi.org/10.1016/j.avb.2013.12.003.

Rinehart, J. K., Yeater, E. A., Musci, R. J., Letourneau, E. J., \& Lenberg, K. L. (2014). The role of ethnicity, sexual attitudes, and sexual behavior in sexual revictimization during the transition to emerging adulthood. Child Maltreatment, 19, 178-187. http://dx.doi.org/10.1177/1077559514551946.

Risser, H.J., Hetzel-Riggin, M.D., Thomsen, C.J., \& McCanne, T.R. (2006). PTSD as a mediator of sexual revictimization: The role of reexperiencing, avoidance, and arousal symptoms. Journal of Traumatic Stress, 19, 687-698. http://dx.doi.org/10.1002/jts.20156. 
Romer, D., Black, M., Ricardo, I., Fiegelman, S., Kaljee, L., Galbraith, J., . . Stanton, B. (1994). Social influences on the sexual behavior of youth at risk for HIV exposure. American Journal of Public Health, 84, 977-985. http://dx.doi.org/10.2105/AJPH.84.6.977.

Roodman, A.A., \& Clum, G.A. (2001). Revictimization rates and method variance: A meta-analysis. Clinical Psychology Review, 21, 183-204. http://dx.doi.org/10.1016/S0272-7358(99)00045-8.

Rossmo, D.K. (1997). Geographic profiling. In J.L. Jackson, \& D.A. Bekerian (Eds.), Offender profiling: Theory, research and practice (pp. 159-175). Hoboken,NJ: John Wiley \& Sons.

Rossmo, D.K. (2000). Geographic profiling. Boca Raton, FL: CRC Press.

Sandberg, D.A., Matorin, A.I., \& Lynn, S.J. (1999). Dissociation, posttraumatic symptomatology, and sexual revictimization: A prospective examination of mediator andmoderator effects. Journal of Traumatic Stress, 12, 127-138. http://dx.doi.org/10.1023/A:1024702501224.

Sartor, C.E., Agrawal, A., McCurcheon, V.V., Duncan, A.E., \& Lynskey, M.T. (2008). Disentangling the complex association between childhood sexual abuse and alcohol-related problems: A review of methodological issues and approaches. Journal of Studies on Alcohol and Drugs, 69, 718-727. http://dx.doi.org/10.15288/jsad.2008.69.718.

Sas, L.D., \& Cunningham, A.H. (1995). Tipping the balance to tell the secret: The public discovery of child sexual abuse. London, ON: London Family Court Clinic.

Sedlak, A.J., Mettenburg, J., Basena, M., Petta, I., McPherson, K., Greene, A., \& Li, S. (2010). Fourth National Incidence Study of Child Abuse and Neglect (NIS-4): Report to Congress. Washington, DC: U.S. Department of Health and Human Services, Administration for Children and Families.

Sidebotham, P. (2001). An ecological approach to child abuse: A creative use of scientific models in research and practice. Child Abuse Review, 10, 97-112. http://dx.doi.org/10.1002/car.643.

Simmel, C., Postmus, J., \& Lee, I. (2012). Sexual revictimization in adult women: Examining factors associated with their childhood and adulthood experiences. Journal of Child Sexual Abuse, 21, 593611 Retrieved from http://www.tandfonline.com/doi/abs/10.1080/10538712.2012.690836.

Simons, R., \&Whitbeck, L. (1991). Sexual abuse as a precursor to prostitution and victimization among adolescent and adult homeless women. Journal of Family Issues, 72, 361-379. http://dx.doi.org/ 10.1177/019251391012003007.

Smalls, S.A., \& Kerns, D. (1993). Unwanted sexual activity among peers during early and middle adolescence: Incidence and risk factors. Journal of Marriage and the Family, 55, 941-952. http://dx .doi.org/10.2307/352774.

Swanston, H.Y., Parkinson, P.N., Oates, R.K., O’Toole, B.I., Plunkett, A.M., \& Shrimpton, S. (2002). Further abuse of sexually abused children. Child Abuse $\mathcal{E}$ Neglect, 26, 115-127. http://dx.doi.org/ 10.1016/S0145-2134(01)00311-8.

Tapia, N.D. (2014). Survivors of child sexual abuse and predictors of adult re-victimization in the United States: A forward logistic regression analysis. International Journal of Crimininal Justice Sciences, 9, 64-73.

Testa, M., Hoffman, J.H., \& Livingston, J.A. (2010). Alcohol and sexual risk behaviors as mediators of the sexual victimization-revictimization relationship. Journal of Consulting and Clinical Psychology, 78, 249-259. http://dx.doi.org/10.1037/a0018914.

Ullman, S.E., \& Vasquez, A.L. (2015). Mediators of sexual revictimization risk in adult sexual assault victims. Journal of Child Sexual Abuse, 24, 300-314. http://dx.doi.org/10.1080/10538712.2015.1006748.

Urquiza, A.J., \& Goodlin-Jones, B.L. (1994). Child sexual abuse and adult revictimization with women of color. Violence and Victims, 9, 223-232 Retrieved from http://www.ncbi.nlm.nih.gov/ pubmed/7647044. 
Van Bruggen, L.K., Runtz, M.G., \& Kadlec, H. (2006). Sexual revictimization: The role of sexual selfesteem and dysfunctional sexual behaviors. Child Maltreatment, 11, 131-145. http://dx.doi.org/10 $.1177 / 1077559505285780$.

Waldron, J.C., Wilson, L.C., Patriquin, M.A., \& Scarpa, A. (2015). Sexual victimization history, depression, and task physiology as predictors of sexual revictimization: Results from a 6-month prospective pilot study. Journal of Interpersonal Violence, 30, 622-639. http://dx.doi.org/10.1177/ 0886260514535258.

Walsh, K., Resnick, H.S., Danielson, C.K., McCauley, J.L., Saunders, B.E., \& Kilpatrick, D.G. (2014). Patterns of drug and alcohol use associated with lifetime sexual revictimization and current posttraumatic stress disorder among three national samples of adolescent, college, and householdresiding women. Addictive Behaviors, 39, 684-689. http://dx.doi.org/10.1016/j.addbeh.2013.12.006.

Wolfe, D.A., Wekerle, C., Gough, R., Reitzel-Jaffe, D., Grasley, C., Pittman, A., .. Stumpf, J. (1996). The youth relationships manual: A group approach with adolescents for the prevention of woman abuse and the promotion of healthy relationships. Thousand Oaks, CA: Sage Publications.

Wolfe, D.A., Wekerle, C., Scott, K., Straatman, A., Grasley, C., \& Reitzel-Jaffe, D. (2003). Dating violence prevention with at-risk youth: A controlled outcome evaluation. Journal of Consulting and Clinical Psychology, 71, 279-291. http://dx.doi.org/10.1037/0022-006X.71.2.279.

Wolfteich, P., \& Loggins, B. (2007). Evaluation of the children's advocacy center model: Efficiency, legal and revictimization outcomes. Child and Adolescent Social Work Journal, 24, 333-352. http://dx.doi.org/10.1007/s10560-007-0087-8. 